\title{
OPPORTUNITIES FOR SOLVING URBAN AND ENVIRONMENTAL PROBLEMS BY PROGRESSIVE CITY LOGISTICS TOOLS
}

\begin{abstract}
At present, high traffic intensity level on the roads currently saturates a great demand for individual transportation. Mobility is an important part of everyday activities in cities. The increasing number of passenger and freight vehicles on the widening transport infrastructure raises several problems. The range of use of public passenger transport does satisfy enough the citizens needs and its use is constantly decreasing, especially in the new EU countries. One of the reasons is also the growing sale and production of new passenger cars in the EU, resulting in congestion in the road infrastructure of cities and environmental problems. These issues are dealt with the modern City Logistics concept. The contribution focused on the basic principles of city logistics, the reasons for its development and, in particular, the possibilities of practical use. An example is the city of Trenčín in Slovakia, where a regional rail passenger transport is proposed for city traffic service including Park and Ride system.
\end{abstract}

Keywords: urban, transport, logistics, environment, city

Tomáš Čechovič ${ }^{1}$

${ }^{1}$ Faculty of Operational and Economics of Transport and Communications, University of Žilina, Univerzitná 8215/1,01026 Žilina, Slovakia; +421/41513 3434; tomas.cechovic@fpedas.uniza.sk

Milan Dedík ${ }^{2}$

${ }^{2}$ Faculty of Operational and Economics of Transport and Communications, University of Žilina, Univerzitná 8215/1,01026 Žilina, Slovakia; +421/41513 3434; milan.dedik@fpedas.uniza.sk

Martin Kendra ${ }^{3}$

${ }^{3}$ Faculty of Operational and Economics of Transport and Communications, University of Žilina, Univerzitná8215/1,01026 Žilina, Slovakia; +421/41513 3429; martin.kendra@fpedas.uniza.sk

Vladimír Lupták ${ }^{4}$

${ }^{4}$ Department of Transport and Logistics, Institute of Technology and Business in České Budějovice, Okružni 517/10, 37001 České Budějovice, Czech Republic; luptak@mail.vstecb.cz

Borut Jereb $^{5}$

${ }^{5}$ University of Maribor, Mariborska cesta 7, 3000 Celje, Slovenia; +386 342853 62; borut.jereb@um.si

\section{Introduction}

High traffic intensity level on the roads is caused by a great demand for individual transportation. The congestion level is also reflected in the accident rate, which is still very high despite the various measures to reduce them compared to other European countries. Many traffic accidents in cities, as well as high traffic intensity, inadequate capacity of urban communications, result in the emergence of crisis situations. It leads to air pollution and the greenhouse effect and there is an essential problem with excessive energy consumption.

One possible tool for preventing crisis situations in cities is the concept of City logistics. This part of logistics is very important because the movement, transport and handling of material are an influential part of the logistical chain.

Margins are up and down $2.5 \mathrm{~cm}$, left and right 2 $\mathrm{cm}$. Before the title of paper are left 4 free lines.

Between two columns a space of $6 \mathrm{~mm}$ is to be left.

The first line of the paragraph is to be shifted $7 \mathrm{~mm}$ from the left margin.

The headings of introduction, chapters, sub-chapters, acknowledgement and references are printed in small letters in $10 \mathrm{pt}$ Bold-Regular type and aligned left Style Normal.
Headings of chapters and sub-chapters are numbered by one Arabic numeral and sub-chapters by two numerals between and after every numeral are dots.

The titles of chapters, sub-chapters, conclusions, acknowledgement and references should be separated from the text by the one-line interval.

\section{Modern tools for energy consumption monitoring}

Considering the high intensity of passenger and freight vehicles, high fuel and energy consumption is expected. There are currently several modern methods and analyzes that monitor and evaluate this consumption. Subsequently, they try to find the optimal solution and optimal variant of transport modes that will be the least energy intensive. There are explained modern tools for energy consumption monitoring, specifically Well-toWheels Analyses and Standard EN 16258:2012 in this section.

\subsection{Well - to - Wheels Analyses}

Well-to-wheel analysis (WTW) refers to specific lifecycle analysis applied to transportation fuels and their use in vehicles. The WTW stage includes resource extraction, fuel production, delivery of the fuel to a 
vehicle, and end use of fuel in vehicle operations. Although feedstock for alternative fuels do not necessarily come from a well, the WTW terminology is adopted for transportation fuel analysis.

The WTW by JEC pursue the objectives of estimating greenhouse gas emissions, energy efficiency and industrial costs of a wide range of automotive fuels and power-trains options significant for Europe in 2020 and beyond.

Each WTW analysis consists of two parts. The first is called Well to Tank Analysis (WTT) from source to tank. Assessment of energy intensity and production of emissions in the gas industry in individual stages of production. Storage of fuel cells, mainly used for the production of raw materials, for transport of natural gas, for transport, production of fuel and distribution to gas stations.

The second part is called Tank to Wheels (TTW) analysis. It assesses the energy intensity and production of greenhouse gas emissions from vehicle fuel combustion. It takes into account the quality of individually produced fuels and also the possibility of burning different types of fuels in internal combustion engines. Together, these two parts take into account the entire life of the individual types of fuels from the well to wheel.

The conclusions can be summarized as follows:

- the key role in the production of GHG emissions and in energy consumption is played not only by the character of the motor fuel and the way it is produced but also by the efficiency of the drive unit in the vehicle

- An alternative to renewable fuels can bring significant reductions in GHG emissions, but generally at a higher cost of energy

- the results of the environmental impact assessment must always be further evaluated in terms of real resources, practical feasibility, cost levels and positive public acceptance

- moving from fossil to alternative fuels from renewable sources is currently very expensive. Reducing GHG emissions always results in increased costs. However, higher costs may not automatically mean a greater reduction in GHG emissions.

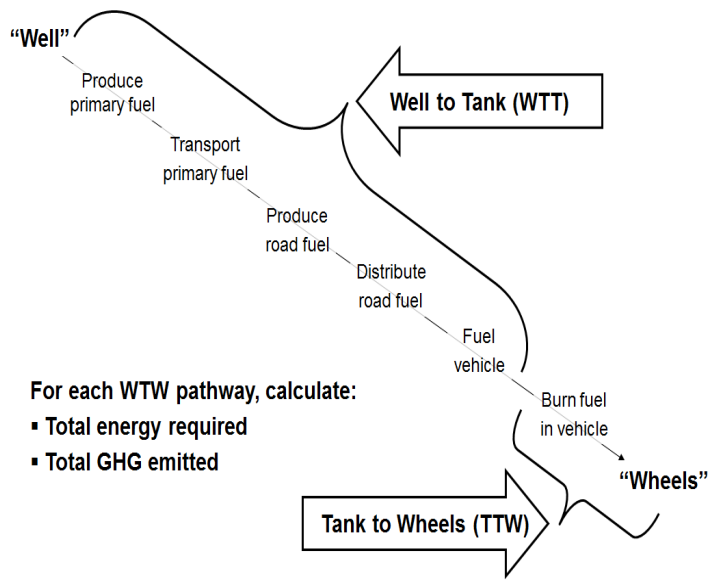

Fig.1. Graphic representation of Well-to-Wheels Analysis

The outcome serves as a sound and broadly accepted scientific reference.

- WTW differs from a Life Cycle Analysis (LCA), as it does not consider energy and emissions involved in building facilities and the vehicles, or end of life aspects.

- WTW analysis focuses on and - TTW), that is the major contributors to lifetime energy use and GHG emissions.

- No estimates of overall "costs to society" such as health, social or other speculative cost areas are made.

- Assumes all plants and vehicles to meet current and incoming future regulations. When considering regulated pollutants, all plants and vehicles are assumed to meet current and incoming future regulations.

\subsection{Standard EN 16258:2012}

This European Standard EN 16258:2012 Methodology for calculation and declaration of energy consumption and GHG emissions of transport services (freight and passengers) specifies a general methodology for calculation and declaration of energy consumption and greenhouse gas emissions (GHG) in connection with the provided services (cargo, passengers or both). It specifies general principles, definitions, system boundaries, methods of calculation, allocation rules (allocation, assignment) and recommendations on information to support the standardized, accurate, reliable and verifiable declarations regarding energy consumption and greenhouse gas emissions associated with the freight service. It also contains examples of the use of these principles.

The calculation for one given transport service must be performed using the following three main steps:

- $\quad$ step 1: identification of the various sections of the service,

- $\quad$ step 2: calculation of energy consumption and greenhouse gas emissions for each section, 
- $\quad$ step 3: sum the results for each section.

The standard does not consider only the secondary emissions produced and energy consumed during the fuel combustion (energy conversion from fuel to mechanical energy), as well as "Naše more" 65(4)/2018., pp. 192-196 primary, incurred in the extraction, production and distribution.

- ew - well-to-wheels energetic factor for the defined fuel,

- gw - well-to-wheels emissions factor for the defined fuel,

- et - tank-to-wheels energetic factor for the defined fuel,

- gt - tank-to-wheels emissions factor for the defined fuel.

Well-to-wheels is "well on wheels", that also covers primary and secondary emissions and consumption. Somewhere this factor is also called as LCA (life-cycleanalysis). The tank-to-wheels factor is thinking only of secondary emission and consumption. This Standard specifies the general methodology for calculation and the declared value for the energetic factor. The factor in greenhouse gas emissions must be selected in accordance with Annex A Emission gases are composed of several individual components (gas). Each one has different chemical and physical properties and participates in environmental degradation. In order to compare emissions from different activities, fuels, vehicles, where emissions have a different track, and one representative unit must be designed for the purpose of comparison. This is the CO2 equivalent, which is a measure of the specific emissions impact similar to the impact of $\mathrm{CO} 2$. The label is $\mathrm{CO} 2 \mathrm{e}$ (equivalent)

\section{City logistics}

The definition of City Logistics follows from the logistics definition: "Logistics is an interdisciplinary science that deals with the coordination, alignment, interconnection and optimization of the materials, information and finance flow in terms of customer satisfaction with optimal spending. "City logistics is the process of optimizing logistics and transport activities, involving various companies with the support of advanced information systems in the city with regard to the transport environment and its impact on the emergence of congestion, safety and energy savings. Therefore one of the tasks of city logistics is to provide comprehensive transport serviceability.

There are cities in many European countries that are beginning to have problems with the traffic situation, although we can not fully compare the problems of our cities with the problems of major European and world cities. Cities try to handle these situations with different measures and drive as much traffic out of town as possible. Of course, most of these measures, especially construction, have a particular impact on transit traffic, when it is possible to route this kind of out-of-town traffic through the construction of by-pass roads. However, the problem remains with the organization of source and destination traffic that is heading directly to the city. It is precisely the solution to these problems in the cities that gave rise to the emergence of city logistics.

City logistics is part of logistics that deals with issues related to the movement of goods flows and means of transport within the city. Therefore, the primary task is the organization of passenger and freight transport in cities and the organization of goods flows and flows of consignments entering or leaving the city. The main reason for this new direction in logistics was the increase in the number of vehicles in cities.

In the understanding of city logistics, related only to the freight sector, three stakeholders - the carrier, the selfgovernment and the private sector - are involved. It is the triangle of city logistics. If we extend the scope of city logistics to the area of passenger transport, we also need to increase the number of participants who will be involved in the development of solutions. These are, in particular, passenger transport undertakings, police forces and, last but not least, citizens.

The basic principles of city logistics have been elaborated in a number of expert and scientific papers and theses. A comprehensive approach gives Cisarova :"Given that city, logistics is perceived in a number of countries to be essentially negative and not conceptually addressed, it is appropriate to define the preparation and phases that should be preceded by the introduction of a quality global concept. First of all, it is necessary to resolve the issue of transit traffic. The city logistics itself solves or should solve only the problems arising from traffic-logistic service, not heavy freight transport. However, there are cities that have major problems with transit, but they are smaller towns with less than 50,000 inhabitants located on busy 1 st and 2 nd class roads. Transit traffic, as well as transit traffic, can be guided by traffic restrictions".

This issue is also addressed to a large number of transport experts and scientists. For example, Julian Allen, Christian Ambrosini, Michale Browne, Daniele Patier, Jean-Louis Routhier and Alan Woodburn propose a wide review of survey methods that have been carried in Europe, based on the conclusions of the BESTUFS II project. From survey work carried out with experts in 11 European countries, a comparison of urban freight transport data collection efforts is made to better understand what currently takes place and to identify examples of good practice. Authors observe that the extent of urban freight data collection varies significantly between the European countries, as existing urban freight data comes mainly from the disaggregation of national survey results. Finally, authors identify a set of gaps in data collection, as well as the need for greater standardization in data collection methods and in analysis and reporting of this data.

Jesus Gonzalez-Feliu, Routhier, J. L et al propose a statistical-based modelling approach to propose a data estimation tool that can be transposed to different cities, 
avoiding the needs of making very costly surveys. The proposed framework needs standard inputs able to be obtained by public authorities and/or private stakeholders to make a diagnosis of urban logistics in current situations. The joint process of collecting data and modelling is described, and the different modules of the framework are presented. The authors conclude by presenting the main applications and further developments.

However, at present, it is important to address, in particular, the solution of city logistics in passenger transport. The authors of the contribution perceive city logistics as an important tool that can optimize energy intensity and environmental problems too. Therefore, the contribution is a kind of link the modern energy consumption methods analysis, city logistics and using railway transport in cities as an ecological transport mode.

\subsection{Reasons for creating the city logistics}

There are a number of reasons why city logistics is becoming more and more important. These include:

- Environmental: the negative impacts of transport on its surroundings are generally known (noise, exhales, soil cover, etc.). By proposing effective solutions to urban and freight transport in cities, these negative impacts can be reduced;

- Transport: the road network in the cities has been diminished during its construction to a lower capacity. Today, however, the traffic flow is far higher than previously thought. Therefore, measures in city logistics can at least partially solve this situation;

- Living standards in the city: a city is a place for its inhabitants to provide not only their living needs but also their social needs. Improving the living standards of city residents can greatly help to improve the traffic situation, mitigate negative environmental impacts, or reduce traffic in the chosen area or time.

\subsection{Opportunities for solving urban and environmental problems in practice}

Solving problems related to increasing the number of vehicles in cities can be solved in a number of ways, but finding an optimal solution is not easy. City Logistics offers a lot of suitable logistics concepts for passenger and freight transport optimization, which usually consist of one or more combinations of the following city logistics approaches:

- Vehicle entry restrictions or permissions; depending on the type of vehicle (size, weight, amount of produced emissions), vehicle entry is permitted or prohibited in a particular area. Mostly, the weight limit applies to the total weight and width of the vehicle or to certain emission limits.

- Paid communications and toll-road fee system; in this case, to introduce tolls for selected types of vehicles that are interested in entering the marked part of the city that is subject to the city toll system. This solution can reduce the number of unacceptable vehicles on toll roads on the one hand, and it can be beneficial for the city budget on the other hand,

- Night supply; when the supply is done at night, the vehicles are avoided by the daily traffic peaks while not feeding them. This results in benefits such as shorter driving times, the possibility of using larger vehicles to replace several small ones, reducing emissions and fuel consumption, fewer roads, modes of transport should be achieved, and consequently the less number of journeys,

- Distribution of goods by other means of transport. By introducing this measure, a modal shift of the goods to ecologically acceptable

- Making urban transport more attractive; only the high-quality, fast-moving urban public transport at regular intervals should motivate citizens to prefer public passenger transport to individual motoring.

- The use of the urban rail transport kinds as a main means of transport; in large cities with built-up tramways, overground and underground railways (metro), this mode of transport should form a transport system and should provide passengers with an attractive concept of transport.

- Utilization of the rail network (or private sidings) for city traffic service. Several railway lines in many cities pass relatively close to the centre and there is a low number of trains. There are also unused private sidings. In this case, there is a possibility of the new trains introduction as public transport, whereby these trains will use the existing regional or main lines private sidings.

- Using the systems such as „Park and Ride“, „Kiss and Ride“, „Bike and ride“, the system of sharing transport" and so on.

- Support for the walking and cycling by the building the paths and cycle tracks.

\section{Practical use in the city of Trenčín by using railway transport}

There is a problem with an excessive increase in individual car transportation thus also congestion in the many Slovak cities. The problem has been appearing for last year not only in big cities but in small towns too. Instead of creating alternatives for the city to create a parking space on the fringe of the city before entering its centre, the large number of cars park directly in its 
narrow centre and core, resulting in an increase in the number of cars in the city centre.

For example, these problems are actually in the city of Trenčín which had a total of 54,916 inhabitants according to the population survey in January 2018. Although the city charged almost all the parking places in the centre and close the city centre, the problem has not been solved yet. If there is no option to park the motor vehicle in the parking garages on the periphery, the drivers will have to park their vehicle in the city centre.

\subsection{The proposal of the solution by using rail transport}

In accordance with the city logistic concept is proposed to extensive usage of rail transport. A suitable way to solve the present situation is to use the existing railway lines or private sidings passing through the city of Trenčín and ensure their operation at dense intervals, thus creating the "Urban railway transport". This should create an alternative way to go through the city by a private car in order to connect the city centre with its other parts more efficiently.

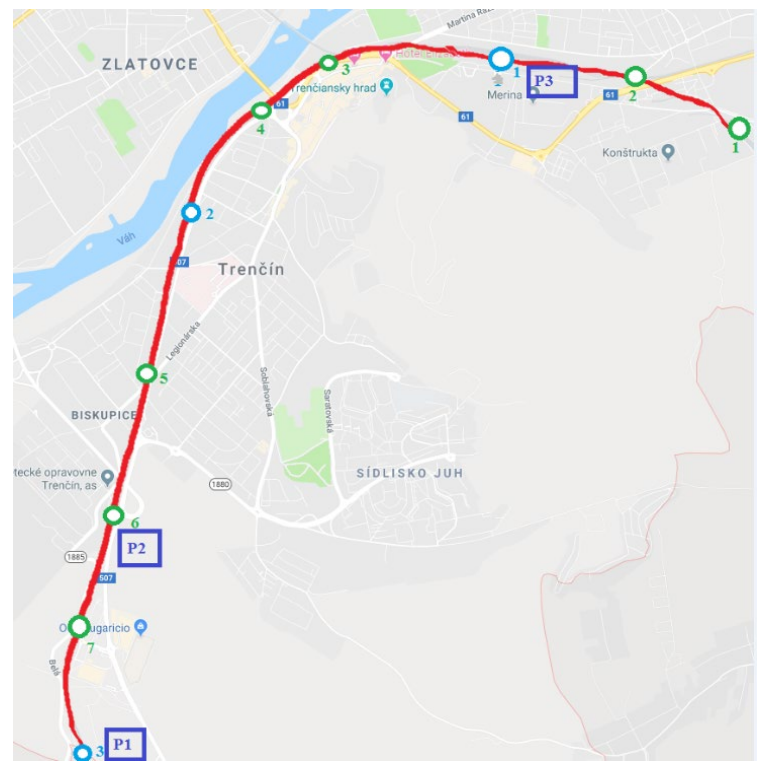

Fig. 2. Suggested stops in Trenčín

Start of the route is proposed on the rail leading to the area of military siding on the estate housing „Pred Pol'om“" (no. 1, green colour) and continues through the railway station Trenčín (no. 1, blue colour), further down the railway line no.143 through the stop „Trenčín predmestie“ (no. 2, blue color) to, Trenčianska Turná“ (no. 3, blue color) as the final stop where the train units will change direction. The private siding belongs to the
Slovak Army, there is an average of 1 train per year, and its use is very problematic but possible.

The proposed route should cooperate together with the proposed parking and applying appropriate measures, such as the cost of using these car parks, which should include the ticket to the proposed train. In addition to the priority objective, an alternative to public transport buses will also be created along the entire route. Thus, not only the city's inhabitants but also the entrants can go from one side of Trenčín to another or to the city centre and back faster.

The calculation of the interval run from the new „Pred Pol'om“ stop to „Trenčianska Turná“ station at the intended average speed of $35 \mathrm{~km}$ per hour and the total distance 6,720 meters, which is considered with 30 seconds additional time for the motor starting run and stopping, and 30 seconds for the dwell time in 10 of 12 stops during the whole ride, the result of running time is 20.5 minutes. It means the train units should ensure the entire territory traffic service theoretically over 20 minutes. Also, they would do three back runs during one hour if they did not give priority to any other passengers or freight train.

There are proposed total 10 stops in the given order, with 3 already existing stops (marked by blue colour in figure 2) and 7 new proposed stops (marked by green colour in figure 2).

\subsection{Usage of the Park and Ride transport system}

One of the most widespread problem-solving systems in the city is Park and Ride (P \& R), "park and go by public transport". The P \& R system is a typical application of intelligent transport systems. It includes parking places and other facilities that enable the interconnection of individual and public transport and combine their advantages. The basic task is to enable an advantageous transfer to urban public transport, thus reducing the number of passengers to the city centre by individual transport.

On the proposed transport route is important to build three catch car parking in front of the centre of Trenčín. The first car parking (A) would serve for cars coming from Banovce nad Bebravou. The parking is designed in the area between the railway and the existing local road, located at the railway station at the beginning of Trenčianska Turná. The second car parking (B) should be built at a downhill run from the D1 highway, which should primarily serve to shut-down cars from the D1 motorway and to offer them the possibility of parking in the contact with rail transport. 


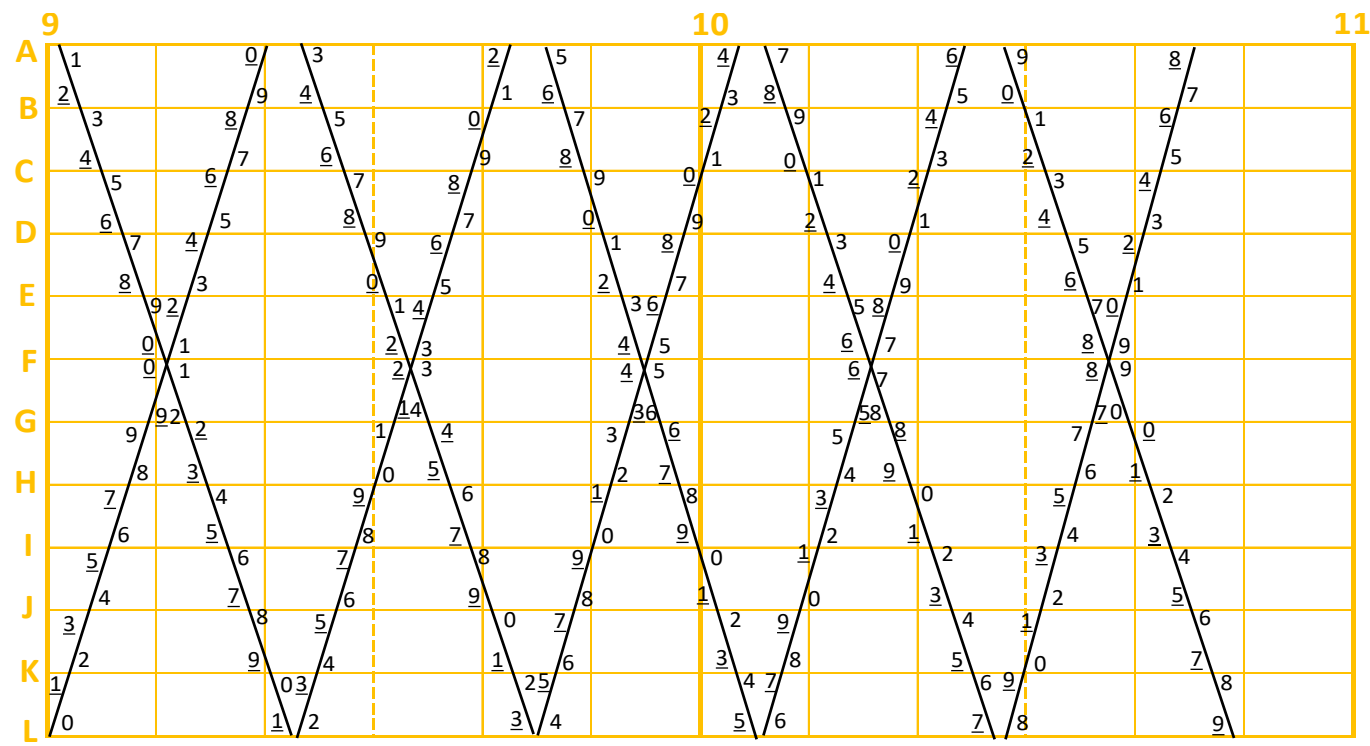

Fig. 3. A preview of two hours period train traffic diagram

\section{Conclusion}

At present, mobility is a part of everyday activities in cities. The increasing number of passenger and freight vehicles on the widening transport infrastructure causes a number of problems that can not be solved alone, but also in terms of impacts on the whole area. The similar problems are in the city of Trenčín. The measures, that have been taken so far, have not been able to disburden the city from frequent congestion and traffic collapse. These problems preclude to improve the transport service in the city.

Due to this persistent unfavourable situation in the city of Trenčín, the purpose of the contribution was to propose measures for the use of regional passenger railway transport for the city transport service. To meet this goal, specific measures have been proposed for the deployment of the transport system and technology together with regional rail transport. For Trenčín, the proposal brings new alternatives to solve the transport problems and to reduce the intensity of individual car traffic, thus relieving the city centre from a large amount of road traffic. At the same time, it supports public transport systems and also the use of regional rail transport, thereby improving the ecological and environmental aspects of the city.

The proposed concept that is being considered in Trenčín, should become a key global technology in urban logistics. It should help optimize passenger transport in cities and tackle global transport problems, as well as to reduce emissions and greenhouse gases in the city, thereby improving the urban environment.

The optimal solution to this issue would be to electrify this particular line and achieve the highest possible occupancy of railway vehicles.

\section{Acknowledgements}

The paper is supported by the VEGA Agency under Project 1/0095/16, "Assessment of the quality of connections on the transport network as a tool to enhance the competitiveness of public passenger transport system", that is solved at Faculty of Operations and Economics of Transport and Communication, University of Žilina.

\section{References}

Ambrosini, C., \& Routhier, J. L. 2004. Objectives, methods and results of surveys carried out in the field of urban freight transport: an international comparison. Transport Reviews, 24(1), 57-77.

Blašković, Z., J.; Abramović, B.; Šipuš, D. 2017. A Strategic Model of Sustainable in the city of Zagreb and its Surrounding Area, In: International Journal for Traffic and Transport Engineering (IJTTE) 7(4): 430-442

Cisarova H., 2012 Modelling of transport services in the selected area using city logistics. in Czech, Dissertation thesis, University of Pardubice, Czech Republic.

Čechovič T., 2018 Advisement of the use of a regional railway transport on the city Trenčín. in Slovak, Diploma thesis, Žilinská univerzita v Žiline, Slovakia.

Dedík, M., Gašparík, J., Záhumenská, Z. 2017 Quality assessment in the logistics of rail passenger transport. In: Logi 2017, Conference Proceedings, 18th International Scientific Conference, Ceske Budejovice, Czech Republic, 2017, Vol. 134, ISSN: 2261236X, DOI: 10.1051/matecconf/201713400009.

Jebli, B. M., Youssef, B. S., Apergis, M. 2019 The dynamic linkage between renewable energy, tourism, CO2 emissions, economic growth, foreign direct investment, and trade. In: Latin American Economic Review, Vol. 28, Issue 1, 2019, Article number 2

Kendra M., Mašek, J. 2008 I, Electronic technical journal on technology, technology and logistics in transport. In: Perner's Contacts, ISSN 1801-674X vol. 3, no. 3, 2008

Kudláč, Š., Majerčák, J., Majerčák, P. 2017 Comparison of different variants of logistics chain with the use of air 
transport using the software application. In: International conference on Air transport - INAIR 2017, Transportation Research Procedia, 2017, Vol. 28, pp. 45-50. ISSN 2352-1457.

Martinez de Salazar, E., García Sanz-Calcedo, J. 2019 Study on the influence of maintenance operations on energy consumption and emissions in healthcare centres by fuzzy cognitive maps. In: Journal of Building Performance Simulation Vol. 12, Issue 4, 4 July 2019, Pages 420-432, University of Extremadura, Badajoz, Spain

Pečený, L., Gašparík, J., Gáborová, V. 2016. Development of public tender of paths ordering in long-distance rail transport in Slovak Republic. In: ICTTE Belegrad 2016: Proceedings of the 3rd International Conference on Traffic and Transport Engineering ICTTE, Belgrade, Serbia, City Net Scientific Research Center, 2016, pp. 462-466. ISBN 978-86-916153-3-8.

Rybička I., Stopka, O., L'upták, V., Chovancová, M., Droždziel, P. 2018 Application of the methodology related to the emission standard to specific railway line in comparison with parallel road transport: A case study; Vol. 244, 5 December 2018, Article number 03002; 3rd Innovative Technologies in Engineering Production, ITEP 2018; Bojnice; Slovakia; 11 September 2018 through 13 September 2018; Code 143364

Skrúcaný T.; Kendra, M.; Škorupa, M. 2017. Comparison of chosen environmental aspects in individual road transport and railway passenger transport. In Conference: 12th International Scientific Conference of Young Scientists on Sustainable, Modern and Safe Transport, 806-811p.

TRENCIN-INAK.SK, 2018. Online available:http://www.trencin-inak.sk/actuality.php

TRENCIN.SK, 2018. Online available: https://trencin.sk/preobcanov/o-meste/mapy-mesta/

Vidriková D., 2010 City logistics and its importance in the prevention of crisis situations in the city, In: Crisis Management, vol. 9, no. 2, 2010, online available: http://fsi.uniza.sk/kkm/files/admincasopis/KM\%202\%2 02010/ODBORNE/Vidrikova.pdf 